\title{
Immunohistochemical staining of colorectal tissues with monoclonal antibodies to ras oncogene p21 product and carbohydrate determinant antigen 19-9
}

\author{
D C ALLEN, HEATHER FOSTER, J C ORCHIN, J D BIGGART \\ From the Histopathology Laboratory, Belfast City Hospital, Northern Ireland
}

SUMMARY Two monoclonal antibodies were applied to benign, dysplastic, and malignant human colorectal tissues using immunohistochemical techniques on formalin fixed paraffin embedded material. RAP-5 antibody is directed against a synthetic peptide, reflecting an amino acid sequence of the ras oncogene p21 protein product. Despite using several different techniques and antibody dilutions differential staining between the various epithelial populations was not obtained. RAP-5 also showed other tissue components such as plasma cells, histiocytes, fibroblasts, smooth muscle and vascular endothelium. CA19-9 antibody recognises an epithelial surface carbohydrate antigen originally derived from a human colorectal carcinoma cell line: it did not stain normal colorectal mucosa or adenomatous polyps, but showed focal expression of variable strength in regenerative, dysplastic, and cancerous mucosa in ulcerative colitis, and in non-colitic colorectal carcinoma. Neither antibody was found to be a reliable marker of the evolution of malignant mucosal changes, although CA19-9 may be of limited use in confirming adenocarcinoma of gastrointestinal origin.

Recent advances have led to a greater understanding of the role of cellular oncogenes and their products in carcinogenesis in man. ${ }^{12}$ Activated cellular ras oncogenes have been found in several solid tumours, ${ }^{34}$ and their transforming ability on NIH 3T3 fibroblasts has been shown. ${ }^{5}$ They code for a group of cellular proteins (p21) thought to take part in normal proliferation, ${ }^{6}$ and increased expression of the ras oncogene family has been detected by hybridisation analysis in colorectal tumours. ${ }^{7}$ RAP-5 monoclonal antibody is directed against a synthetic peptide sequence, reflecting positions 10-17 of the human ras (Hu-ras) protein product (p21) derived from the T24 bladder carcinoma. ${ }^{8}$ It has been found to show differential ras gene expression in benign and malignant colonic disease. ${ }^{9}$

A further aid to assessing malignant changes in colorectal mucosa has been the use of epithelial tissue markers by applying antibodies to carcinoembryonic antigen, ${ }^{10}$ IgA secretory component, ${ }^{11}$ and epithelial membrane antigen. ${ }^{12}$ Monoclonal antibody CA19-9 reacts with a carbohydrate antigenic determinant (19-9) identified as a sialylated lacto-Nfucopentaose. ${ }^{13}$ It is closely related to epithelial membrane antigen and is found at the epithelial cell

Accepted for publication 3 September 1986 surface. It has been shown immunohistochemically in pancreatic, gastric, and colonic tumours. ${ }^{14}$

The purpose of this study was to assess the use of these antibodies as tissue markers in evolving and established cases of colorectal carcinoma.

\section{Material and methods}

The material in this study came from the files of this hospital. The tissues had been fixed in $4 \%$ aqueous formaldehyde, secondarily fixed in Helly's fluid, and processed to paraffin wax. The sections studied consisted of histologically normal mucosa from the most distant resection limit of non-colitic colorectal carcinomas, plus five rectal adenomatous polyps, three villous adenomas, five colorectal carcinomas, and carcinomas from nine patients with ulcerative colitis, also showing regenerative and dysplastic mucosal changes. The colitic mucosa was assessed for dysplasia using a standardised classification. ${ }^{1516}$ Some of this material also formed the basis of a previous immunoperoxidase study using antibodies to carcinoembyronic antigen and the IgA secretory system. ${ }^{17}$

ANTIBODIES AND IMMUNOHISTOCHEMICAL TECHNIQUES

The RAP-5 monoclonal antibody was a generous gift 
from Dr J Schlom, NIH, Bethesda, USA. It was applied at varying dilutions between $1 / 15000$ and $1 / 25000$ to trypsinised and non-trypsinised sections. Blocking of non-specific binding of antibody to protein was achieved with ovalbumin $1 \%$ and bovine serum albumin. Hydrogen peroxide was used to diminish endogenous peroxidase activity. The NIH protocol, based on a standard avidin-biotin-complex immunoperoxidase procedure, was followed, ${ }^{18}$ and colourisation obtained using diaminobenzidine substrate with a light haematoxylin counterstain. Further sections were stained using indirect immunoperoxidase $^{19}$ and a streptavidin-biotin peroxidase system. $^{20}$ The CA19-9 monoclonal antibody (Histocis CA19-9) was obtained by courtesy of CIS
(UK) Ltd, and it was applied to sections undiluted using the manufacturer's recommended avidin-biotin immunoperoxidase kit. In addition, the indirect and streptavidin-biotin techniques were also used. Immunoperoxidase staining was graded qualitatively as light, moderate, or heavy.

\section{Results}

\section{RAP-5 MONOCLONAL ANTIBODY}

Epithelial staining using this antibody was of a diffuse distribution throughout the cell cytoplasm. There was no accentuation of positivity in the supranuclear Golgi zone, the cell apex, or along the luminal border. Global uniformity of staining was seen in the various

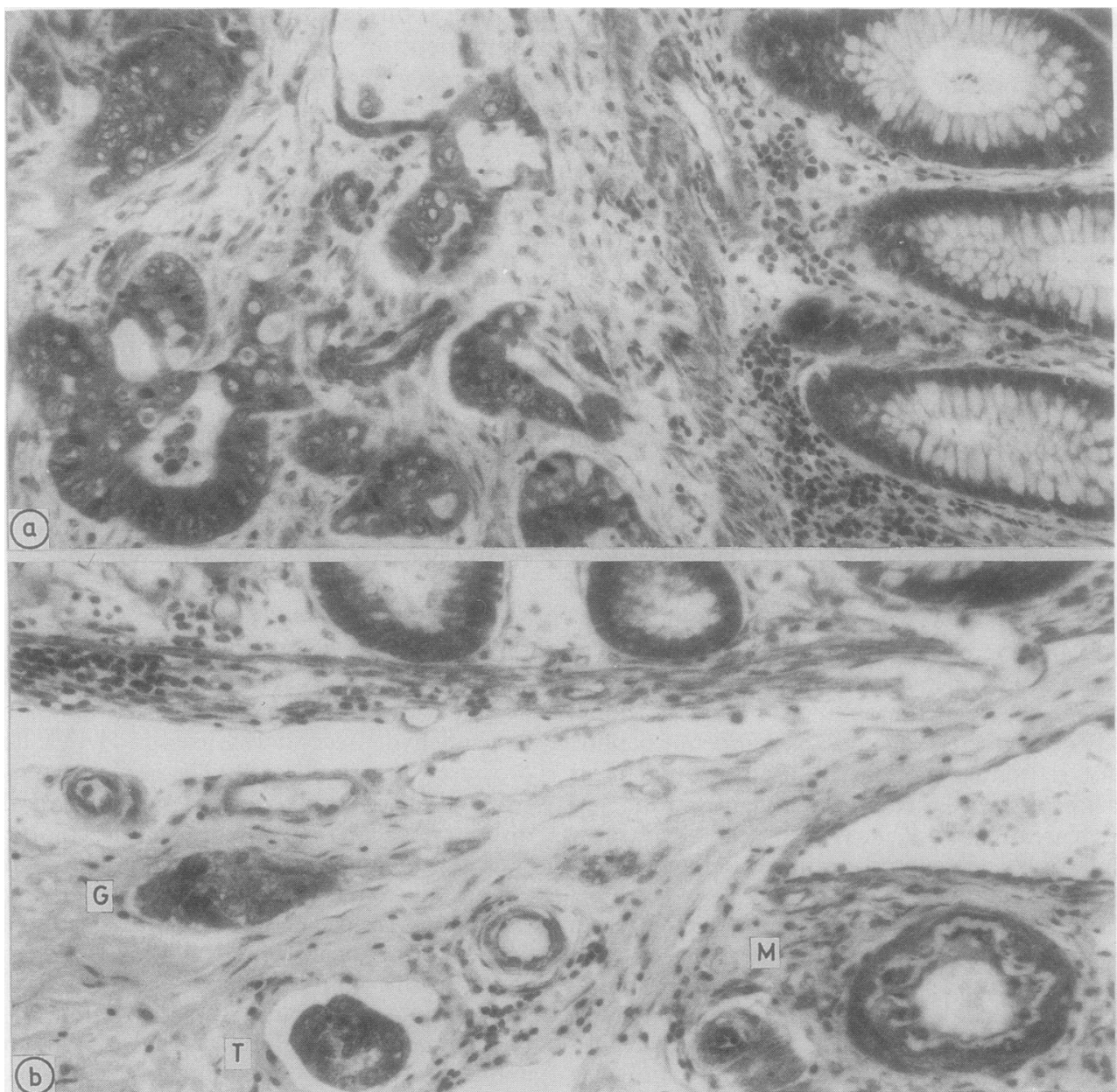

Fig 1 (a) RAP-5 monoclonal antibody. Normal epithelial cells of mucosa, muscularis mucosae and tumour epithelium (left) all show diffuse staining. Goblet cell mucin and tumour stroma is negative. (Avidin-biotin immunoperoxidase.) $\times 230$. (b) RAP-5 monoclonal antibody. Positive staining in ganglion cells $(G)$, lymphatic tumour embolus $(T)$, and vascular muscle coat and endothelium $(M)$. (Avidin-biotin immunoperoxidase.) $\times 270$. 
epithelial populations represented as follows: histologically normal mucosa; mucosa with transitional features; regenerative and dysplastic mucosa in ulcerative colitis; dysplasia in adenomatous polyps and both colitic and non-colitic adenocarcinoma. Nonepithelial components also stained. These included plasma cell cytoplasm, occasionally lymphocyte and histiocyte cytoplasm and fibroblasts, ganglion cells, and nerve branches. The smooth muscle in the muscularis mucosae, the muscle coat, and submucosal vessels also displayed staining product along with the endothelial cells of submucosal vessels and granulation tissue capillaries. Goblet cell mucin and tumour collagenous stroma were negative (fig 1). Differential epithelial staining was not improved by antibody dilution, blocking, and digestion, or by using the alternative immunohistochemical methods. Further colorectal blocks of tissue processed without secondary Helly's fluid fixation showed similar results but with decreased muscle coat reaction.

\section{CA19-9 MONOCLONAL ANTIBODY}

This antibody failed to stain histologically normal and transitional like mucosae. The table summarises the staining of diseased colorectal tissue. Regenerative epithelium in ulcerative colitis showed focal positivity varying from light to heavy. The staining pattern was one of product deposition in the immediate supranuclear and cell apex regions and as a fine luminal rim over the surface epithelium (fig 2). Dysplasia in adenomatous polyps and villous adenomas was negative, but was positive in a focal manner, and of variable strength in ulcerative colitis. This showed cell apex staining, but the surface luminal border was particularly prominent and was sometimes associated with cryptal and surface debris (fig 3 ). Two adenocarcinomas were negative, 12 showed positivity, albeit focal and light in eight, and moderately diffuse or heavy in only four cases of the 13 cancers. The staining pattern was similar to that of dysplasia with luminal rim accentuation. Central debris in tumour acini and diffuse cytoplasmic staining along with single tumour cells surrounded by a halo effect were also seen (fig 4). Using indirect immunoperoxidase

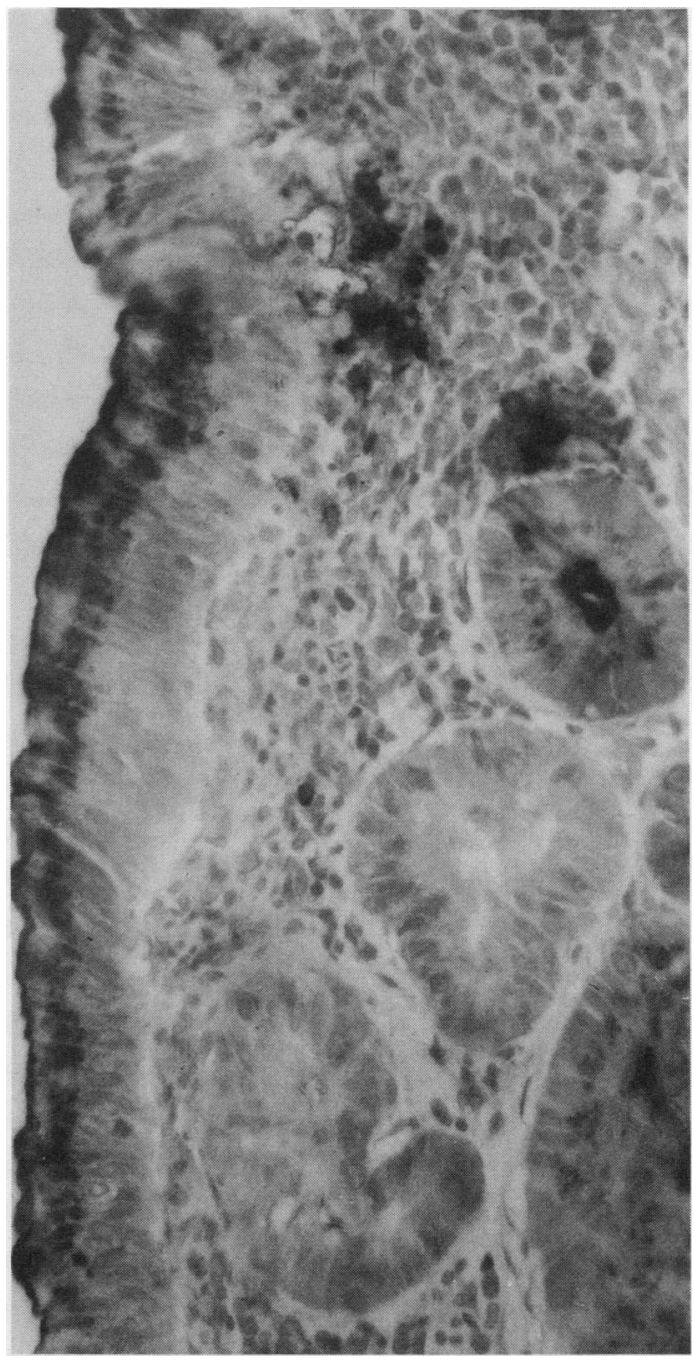

Fig 2 CA19-9 monoclonal antibody. Regenerative epithelium with staining occurring in supranuclear and cell apex regions, and as a luminal surface rim. Two glands (bottom) are negative. (Avidin-biotin immunoperoxidase.) $\times 370$.

Table Staining reaction of monoclonal antibody CA19-9 with colorectal tissues

\begin{tabular}{llllll}
\hline & \multirow{2}{*}{$\begin{array}{l}\text { No of cases } \\
\text { studied }\end{array}$} & Staining intensity & & Moderate \\
\cline { 5 - 6 } Histological diagnosis & 0 & Light & Heavy \\
\hline Regeneration in ulcerative colitis & 14 & 6 & 5 & 1 & 2 \\
Dysplasia in ulcerative colitis & 11 & 5 & 4 & 1 & 1 \\
Adenocarcinoma in ulcerative colitis & 9 & 1 & 6 & 2 & 1 \\
Adenomatous polyp, villous adenoma & 8 & 8 & 2 & 2 \\
Adenocarcinoma & 5 & 1 & & \\
\hline
\end{tabular}




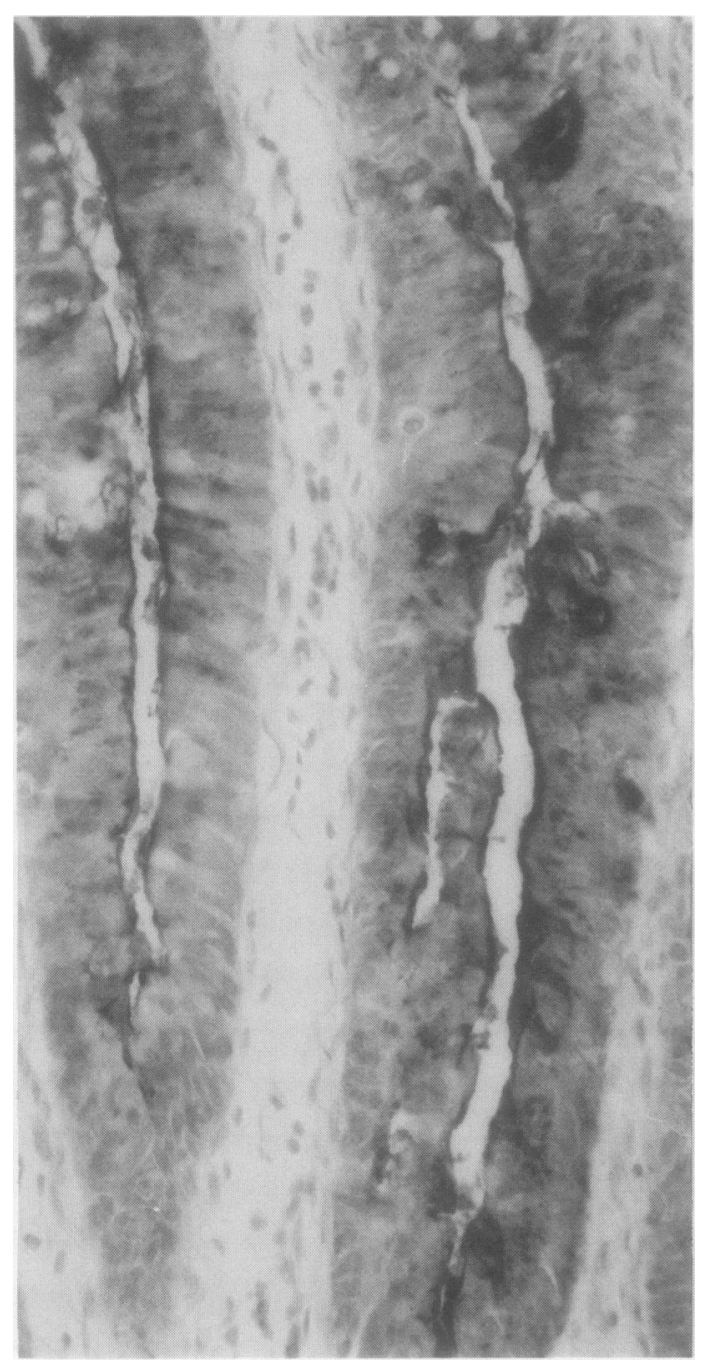

Fig 3 CA19-9 monoclonal antibody. Ulcerative colitis with high grade dysplasia. Staining occurs in cell apex and as a strong luminal surface rim. (Avidin-biotin immunoperoxidase.) $\times 370$.

and streptavidin-biotin peroxidase strengthened the product reaction but did not alter the staining distribution within a given tissue. Goblet cells and non-epithelial components were consistently negative.

\section{Discussion}

Eukaryotic cells contain proto-oncogenes, which code for a number of cell products concerned with normal growth and differentiation. ${ }^{2}$ The $\mathrm{Hu}$-ras gene family elaborate several proteins, with binding and enzyme activities influencing cell metabolism. ${ }^{6}$ Protooncogenes can exert an effect on mucosal proliferation and carcinogenesis, either quantitatively by an increased expression of the normal gene or qualitatively by mutagenesis of the gene sequence. The activated cellular oncogene produces either increased concentrations of normal cellular protein or an abnormal peptide sequence, events favourable to cell transformation. This process may be brought about by encountering a cofactor event such as a chemical carcinogen, viruses, or radiation. Heightened ras gene expression has been described in hybridisation studies in colonic polyps and tumours. ${ }^{7}$ On tissue sections using a different monoclonal to ras p21 (Y13 $259 \mathrm{Hu}$-ras Harvey) than the one presently studied, two groups of workers found variable staining in normal colorectal mucosa and carcinoma, ${ }^{2122}$ with an increased intensity in adenomatous polyps. ${ }^{22}$ RAP-5 antibody has been described as showing preferential staining in human mammary and colonic carcinomas over benign inflammatory and dysplastic lesions in these tissues. ${ }^{89}$ Its expression has been postulated to correlate with the depth of colonic wall tumour invasion and in areas of severe epithelial dysplasia, indicating a relatively late event in malignant transformation. ${ }^{9}$ Our present study did not show differential staining of the various epithelial ces populations or between different levels of tissue in the same lesion. In contrast to the findings of other stud? ies, ${ }^{89}$ we also noted strong staining of non-epitheliaT tissue components as seen previously in the colon ${ }^{21}$ and breast. ${ }^{23}$ Ghosh $e t$ al $^{23}$ recently reported similar findings to ours in a range of breast lesions. We must agree with their interpretation that either RAP-5 detects a normal cell product not enhanced in carcinogenesis, or that it does not show the abnormal p21 product, derived from mutagenesis and oncogene activation, which is necessary for neoplasia. An explanation for the discrepancy in colorectal studies using the two p21 antibodies may be that RAP-5 reacts on solid phase radioimmunoassay with both T24 Hu-ras and Hu-ras Harvey peptides, which show an amino acid difference at position 12 of the p21 molecule. ${ }^{89}$ This indicates RAP-5 reactivity with a group of p21 proteins, and therefore the detection of a specific mutant $\mathrm{p} 21$ product relevant to tumour formation is made less likely. ${ }^{23}$ This in no way excludes the role of ras genes in colonic carcinogenesis but does seem to indicate a limited use in our hands for monoclonal antibody RAP-5 in diagnostic colorectal pathology.

Neoplasia tissue markers include the expression of oncofetal antigens (carcinoembryonic antigen) and the loss of normal cell function with the evolution of malignancy (IgA secretory system). An allied approach has been to raise antibodies against the 


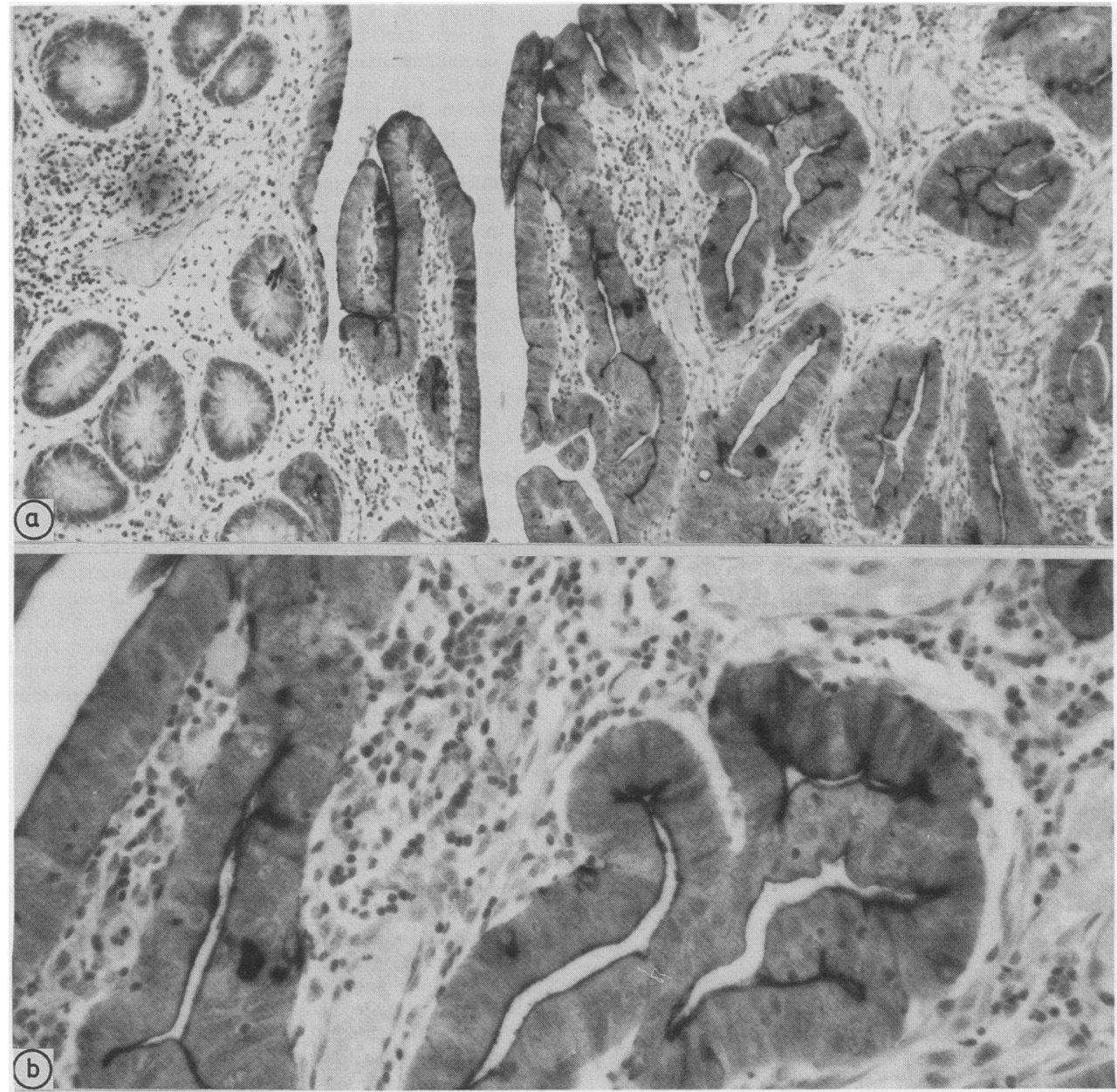

Fig 4 (a) CA19-9 monoclonal antibody. Negative mucosa (left) contrasts with strong epithelial surface staining in adenocarcinoma (right). (Avidin-biotin immunoperoxidase.) $\times 130$. (b) CA19-9 monoclonal antibody. High power view of tumour epithelial surface staining. (Avidin-biotin immunoperoxidase.) $\times 370$.

immunodominant antigen on tumour cell surfaces. $\mathrm{MC} 2$ and $\mathrm{MC4}^{24}$ and antibody to epithelial membrane antigen achieve this by showing cell surface carbohydrate oligosaccharides. Monoclonal antibody CA19-9 recognises a closely related fucosylated pentasaccharide, sialylated lacto- $\mathrm{N}$-fucopentaose, developed by immunisation of BALB/c mice with a human cell line SW1116, derived from a colorectal carcinoma. ${ }^{25} 26$ Its main use has been as a serum tumour marker in upper gastrointestinal disease, ${ }^{27} 28$ and it has been shown in adenocarcinoma tissue sections of stomach, pancreas, and colon. ${ }^{14}$ The findings in this study confirmed positive CA19-9 staining in 12 of 14 colonic carcinomas, although it was focal and light in eight of these 12. Epithelial dysplasia showed variable staining, being totally negative in nine pre- malignant polyps but giving patchy, light deposition in just over half of the regenerative and dysplastic cases of ulcerative colitis. It is possible that CA19-9, like carcinoembryonic antigen and epithelial mucins (personal observations DCA), may reflect not only dysplasia but also regeneration in ulcerative colitis, ${ }^{1729}$ where cell turnover and proliferation is known to be increased. ${ }^{30}$ The supranuclear and cell surface staining of CA19-9 also corresponds to the Golgi apparatus and cell apex localisation of carcinoembryonic antigen seen on ultrastructural study of a human colorectal adenocarcinoma cell line. ${ }^{31}$ The explanation for the spectrum of staining found in similar histological changes within the mucosa remains unanswered. Thus the results for differential staining of these epithelial subtypes were less reliable than the 
previously used carcinoembryonic antigen and IgA secretory system markers. ${ }^{17}$ Therefore, CA19-9 cannot be recommended for diagnostic use in tracing the evolution of malignant changes in the colorectal mucosa, particularly as a basis for discrimination between regeneration and dysplasia in ulcerative colitis. The disparity in staining between non-colitic premalignant polyps and carcinoma is of interest, and further work needs to be done to assess its ability to indicate carcinomatous change within mucosal polyps. At present, CA19-9 may be of limited use to the histopathologist in established malignancy when used in combination with other markers (eg CEA) in confirming metastatic adenocarcinoma of gastrointestinal origin.

In the absence of reliable immunohistochemical markers of colonic regeneration, dysplasia, and carcinoma one can only recommend that the pathologist gains sufficient experience of the spectrum of possible histological changes in colorectal epithelium and that his judgment be refined by application of standardised classifications. ${ }^{1532}$

We are grateful to Dr J Schlom and CIS (UK) Ltd, for donating the antibodies used in this study. We thank Mr PW Hamilton for his advice and Mrs J Hammill, who typed the manuscript.

\section{References}

1 Bishop JM. Viruses, genes and cancer II Retroviruses and cancer genes. Cancer 1985;55:2329-33.

2 Paul J. Oncogenes. J Pathol 1984;143:1-10.

3 Pulciani S, Santos E, Lauver AV, Long LK, Aaronson SA, Barbacid M. Oncogenes in solid human tumours. Nature 1982;300:539-42.

4 Slamon DJ, DeKernion IB, Verma IB, Cline MJ. Expression of cellular oncogenes in human malignancies. Science 1984; 224:256-62.

5 Parada LF, Tabin CJ, Shih C, Weinberg RA. Human EJ bladder carcinoma oncogene is homologue of Harvey sarcoma virus ras gene. Nature 1982;297:474-8.

6 McGrath JP, Capon DJ, Goedel DV, Levinson AD. Comparative biochemical properties of normal and activated human ras p21 protein. Nature 1984;310:644-9.

7 Spandidos DA, Kerr IB. Elevated expression of the human ras oncogene family in premalignant and malignant tumours of the colorectum. Br J Cancer 1984;49:681-8.

8 Horan Hand P, Thor A, Wunderlich D, Muraro R, Caruso A, Schlom J. Monoclonal antibodies of predefined specificity detect activated ras gene expression in human mammary and colon carcinomas. Proc Natl Acad Sci USA 1984;81:5227-31.

9 Thor A, Horan Hand P, Wunderlich D, Caruso A, Muraro R, Schlom J. Monoclonal antibodies define differential ras gene expression in malignant and benign colonic diseases. Nature 1984;311:562-5.

10 Gold P, Freedman SO. Demonstration of tumour-specific antigens in human colonic carcinomata by immunological tolerance and absorption techniques. $J$ Exp Med 1965;121:439-62.

11 Poger ME, Lamm ME. Localisation of free and bound secretory component in human intestinal epithelial cells: a model for the assembly of secretory IgA. J Exp Med 1974;139:629-42.

12 Heyderman E, Steele K, Ormerod MG. A new antigen on the epithelial membrane: its immunoperoxidase localisation in normal and neoplastic tissue. J Clin Pathol 1979;32:35-9.

13 Magnani JL, Nilsson B, Brockhaus M, Zopf D, Steplewski Z,
Koprowski H, Ginsburg V. A monoclonal antibody-defined antigen associated with gastrointestinal cancer is a ganglioside containing sialylated lacto-N-fucopentaose II. J Biol Chem 1982;257:14365-9.

14 Atkinson BF, Ernst CS, Herlyn M, Steplewski A, Sears HF, Koprowski H. Gastrointestinal cancer-associated antigen in immunoperoxidase assay. Cancer Res 1982;42:4820-3.

15 Riddell RH, Goldman H, Ransohoff DF, et al. Dysplasia in inflammatory bowel disease: standardised classification with provisional clinical applications. Hum Pathol 1983;14:931-68.

16 Allen DC, Biggart JD, Pyper PC. Large bowel mucosal dysplasia and carcinoma in ulcerative colitis. J Clin Pathol 1985;38: 30-43.

17 Allen DC, Biggart JD, Orchin JC, Heather Foster. An immunoperoxidase study of epithelial marker antigens in ulcerative colitis with dysplasia and carcinoma. J Clin Pathol 1985;38:18-29.

18 Guesdon JL, Ternynck T, Avrameas S. The use of avidin-biotin interaction in immunoenzymatic techniques. $J$ Histochem Cytochem 1979;27:1131-9.

19 Nakane PK, Pierce GB Jr. Enzyme-labelled antibodies: preparation and application for the localisation of antigens. $J$ Histochem Cytochem 1966;14:929-31.

20 Bonnard C. The streptavidin-biotin bridge technique: application in light and electron microscope immunocytochemistry. In: Polak JM, Varndell IM, eds. Immunolabelling for electron microscopy. Amsterdam: Elsevier Scientific Publications, 1984.

21 Kerr IB, Lee FD, Quintanilla M, Balmain A. Immunocytochemical demonstration of $\mathrm{p} 21$ ras family oncogene product in normal mucosa and in premalignant tumours of the colorectum. Br J Cancer 1985;52:695-700.

22 Williams ARW, Piris J, Spandidos DA, Wyllie AH. Immunohistochemical detection of the ras oncogene $\mathrm{p} 21$ product in an experimental tumour and in human colorectal neoplasms. $\mathrm{Br}$ Cancer 1985;52:687-93.

23 Ghosh AK, Moore M, Harris M. Immunohistochemicat detection of ras oncogene $\mathrm{p} 21$ product in benign and malignan mammary tissue in man. J Clin Pathol 1986;39:428-34.

24 McCarthy NC, Simpson JRM, Coghill G, Kerr MA. Expressioń in normal adult, fetal, and neoplastic tissues of a carbohydrate differentiation antigen recognised by antigranulocyte mouse monoclonal antibodies. J Clin Pathol 1985;38:521-9.

25 Koprowski H, Steplewski Z, Mitchell K, Herlyn M, Herlyn D, Fuhrer P. Colorectal carcinoma antigens detected by hybridoma antibodies. Somatic Cell Mol Genet 1979;5:957-72.

26 Liebowitz A, Stinson JC, McCombs WB, McCoy CE, Mazur KC, Mabry ND. Classification of human colorectal adenocarcinoma cell lines. Cancer Res 1976;36:4562-9.

27 Del Villano BC, Brennan S, Brock P, Bucher C, Liu V, McClure M, Rake B, Space S, Westrick B, Schoemaker H, Zurawski VR Jr. Radioimmunometric assay for a monoclonal antibodydefined tumour marker, CA19-9. Clin Chem 1983;29:549-52.

28 Jalanko H, Kuusela P, Roberts P, Sipponen P, Haglund C, Makela O. Comparison of a new tumour marker, CA19-9 ${ }^{\mathrm{TM}}$, with fetoprotein and carcinoembryonic antigen in patients with upper gastrointestinal diseases. J Clin Pathol 1984;37:218-22.

29 Wager C, Hain F, Breuer H, Olude S, Cremer H, Muller-Walraf R. Immunohistochemical demonstration of carcinoembryonic antigen in normal, transitional and inflamed colonic mucosa Oncodevelopmental Biology and Medicine 1981;2:331-43.

30 Lehy T, Mignon M, Abitbol JL. Epithelial cell proliferation in the rectal stump of patients with ileorectal anastomosis for ulcerative colitis. Gut 1983;24:1048-56.

31 Wolf B, Thompson J, Von Kleist S. Ultrastructural localisation of carcino-embryonic antigen in a continuous human tumour cell line (LS174T) in relation to morphometric investigations. Anticancer Res 1984;4:213-20.

32 Konishi F, Morson BC. Pathology of colorectal adenomas: a colonoscopic survey. J Clin Pathol 1982;35:830-41.

Requests for reprints to: Dr D Allen, Histopathology Laboratory, Belfast City Hospital, BT97AD, Northern Ireland. 